\title{
Phylogenetic Relationships and Uncertain Taxonomy of Pedomicrobium Species
}

\author{
TRACY L. COX AND L. I. SLY* \\ Centre for Bacterial Diversity and Identification, Department of Microbiology, \\ The University of Queensland, Brisbane, Australia 4072
}

\begin{abstract}
The phylogenetic relationships among the species of the genus Pedomicrobium were studied by comparing their 16S rRNA sequences. The Pedomicrobium species form a coherent phylogenetic cluster within the genera of the hyphal budding bacteria in the $\alpha$-Proteobacteria. The sequences of two strains of Pedomicrobium australicum were obtained from DNAs extracted from nonviable freeze-dried cells, which are the only source of material available, and were found to be almost identical (level of similarity, 99.9\%). Overall, the Pedomicrobium species are closely related, with sequence similarities ranging from 96.2 to $99.9 \%$. Pedomicrobium manganicum is phylogenetically the most distantly related species and exhibits the lowest similarity $(96.2 \%)$ with Pedomicrobium americanum. Australian isolate Pedomicrobium sp. strain ACM 3067, P. americanum, and $P$. australicum are all very highly related, with similarities greater than $99 \%$. Pedomicrobium sp. strain ACM 3067 is most closely related to $P$. australicum (level of similarity, $99.6 \%$ ) and $P$. americanum $(99.4 \%$ ). These manganese-oxidizing species are more closely related to the iron-oxidizing species Pedomicrobium ferrugineum than to the other manganese-oxidizing species, $P$. manganicum. Taxonomic uncertainties resulting from the loss of the type culture of $P$. australicum are discussed.
\end{abstract}

In 1988, Sly et al. reported on the characteristics of strains of Pedomicrobium manganicum isolated from manganese-depositing biofilms in drinking water distribution systems in Australia (28). At that time, there were only two valid species of the genus Pedomicrobium, Pedomicrobium ferrugineum and $P$. manganicum $(20,27)$. Later, Gebers and Beese (7) described two new species, Pedomicrobium americanum and Pedomicrobium australicum. Unfortunately, the type strain and a second isolate of $P$. australicum were lost before they could be accessioned for distribution $(13,14,32)$, and we were unable to compare these strains with our isolates, which appeared to be more closely related phenotypically to $P$. australicum and $P$. americanum than to $P$. manganicum.

The absence of a viable type strain of $P$. australicum is contributing to taxonomic uncertainty in the genus Pedomicrobium. The availability of PCR techniques provided an opportunity to amplify $16 \mathrm{~S}$ rRNA genes from nonviable freeze-dried ampoules and to determine the $16 \mathrm{~S}$ rRNA sequences of $P$. australicum for comparison with the sequences of the other Pedomicrobium species and our local isolates. Although $\mathrm{Ge}$ bers and Beese (7) showed that $P$. australicum and $P$. americanum exhibited only 25 to $28 \%$ DNA homology and were separate species as determined by currently accepted standards for DNA-DNA homology levels $(31,35)$, there were no reliable phenotypic characteristics to differentiate the two species. If sufficient differences in the sequences of the 16S rRNAs of $P$. australicum and $P$. americanum can be found, then it may be possible to determine species-specific RNA sequence signatures for designating a neotype strain of $P$. australicum for further study.

\section{MATERIALS AND METHODS}

Microorganisms. Most of the strains used in the study were obtained from the Australian Collection of Microorganisms, Department of Microbiology, University of Queensland, Brisbane, Australia; the only exceptions were $P$. australicum IFAM ST-1306 ${ }^{\mathrm{T}}(\mathrm{T}=$ type strain) and IFAM WD-1355, which were obtained as nonviable freeze-dried material from Peter Hirsch at the Institut für Allgemeine

\footnotetext{
* Corresponding author. Phone: 6173365 2396. Fax: 61733651566. E-mail: sly@biosci.uq.oz.au.
}

Mikrobiologie in Kiel, Germany. Details of the strains are shown in Table 1. Al viable strains were maintained on PSM agar plates (6) and were incubated a $28^{\circ} \mathrm{C}$. Manganese oxidation was verified on PC agar plates (34)

Extraction and purification of genomic DNA. Bacterial growth from PSM agar plate cultures or freeze-dried material of those strains which were nonviable was collected and pelleted by centrifugation in a microcentrifuge at $3,000 \mathrm{rpm}$, and the genomic DNA was isolated by the method of Bollet et al. (2). DNA was released from cells in $1.5-\mathrm{ml}$ microcentrifuge tubes (Treff Laboratories, Degersheim, Switzerland) by heating the tubes in a 650 -W microwave oven for three 1 -min intervals. The concentration of DNA in a sample was estimated by electrophoresing $5 \mu \mathrm{l}$ of purified DNA with $3 \mu \mathrm{l}$ of loading buffer $(0.25 \%$ bromophenol blue and $30 \%$ glycerol in water) and a 1-kb DNA ladder (Gibco, Gaithersburg, Md.) on a $1 \%$ agarose gel containing $5 \mu \mathrm{l}$ of a $10-\mathrm{mg} / \mathrm{ml}$ ethidium bromide solution per $100 \mathrm{ml}$.

PCR amplification of $16 S$ ribosomal DNA (rDNA). A 1- to 3- $\mu$ l portion of bacterial genomic DNA was used in each PCR mixture, as described by Bond e al. (3). The first denaturation step consisted of incubation at $98^{\circ} \mathrm{C}$ for $2 \mathrm{~min}$. The thermal profile of the PCR apparatus (Perkin-Elmer Cetus, Norwalk, Conn.) included repeated cycles of primer annealing at $48^{\circ} \mathrm{C}$ for $1 \mathrm{~min}$, extension at $72^{\circ} \mathrm{C}$ for $2 \mathrm{~min}$, and denaturation at $93^{\circ} \mathrm{C}$ for $1 \mathrm{~min}$. After $28 \mathrm{cycles}$, primer annealing was repeated, and this was followed by a final extension step at $72^{\circ} \mathrm{C}$ for $5 \mathrm{~min}$. The primers used for amplification were primers $27 \mathrm{f}$ and $1525 \mathrm{r}(18)$. The PCR products were purified by using Wizard Mini Preps for DNA purification (Promega, Madison, Wis.) as recommended by the supplier. The concentrations of purified PCR products were estimated by electrophoresing $2 \mu \mathrm{l}$ of each PCR product on a $1 \%$ agarose gel as described above for genomic DNA.

Sequencing of 16S rDNA. Sequencing reactions were carried out by using a PRISM Ready Reaction DyeDeoxy terminator cycle sequencing kit (PerkinElmer/Applied Biosystems Div., Foster City, Calif.). A 1- to 3- $\mu$ l portion of purified PCR product was used per reaction mixture (total volume, $20 \mu \mathrm{l}$ ) along with $9 \mu \mathrm{l}$ of Terminator Premix and $1 \mu \mathrm{l}$ of sequencing primer. Primers $27 \mathrm{f}, 357 \mathrm{f}$ 530f, 803f, 1114f, 1230f, 342r, 519r, 787r, 1100r, 1392r, and 1525r (18) were used to sequence the whole $16 \mathrm{~S}$ rRNA gene in both forward and reverse directions. Extention products were purified, and sequences were determined by automated DNA sequencing with an Applied Biosystems model 373A instrument as recommended by the manufacturer.

Phylogenetic analysis. The full-length 16S rRNA sequences of $P$. ferrugineum ACM $3037^{\mathrm{T}}$, P. manganicum ACM $3038^{\mathrm{T}}$, P. americanum ACM $3090^{\mathrm{T}}, P$. aus tralicum IFAM ST-1306 ${ }^{\mathrm{T}}$ and IFAM WD-1355, and Pedomicrobium sp. strain ACM 3067 were manually aligned with sequences of eight other members of the Proteobacteria, including the nearest known relative, Hyphomicrobium vulgare (30), by using the Escherichia coli sequence as the reference sequence. The sequences of the following strains were obtained from the Ribosomal Database Project, Urbana, Ill. (19): Hyphomicrobium vulgare ATCC 27500 (accession no. X53182), Hyphomonas jannaschiana ATCC 33882 (accession no. M83806), Hirschia baltica ATCC $49814^{\mathrm{T}}$ (accession no. X52909), Rhodomicrobium vannielit ATCC 51194 (accession no. M34127), E. coli (accession no. J01695), Neisseria gonorrhoeae ATCC 19424 (accession no. X07714), Desulfovibrio desulfuricans ATCC 27774 (accession no. M34113), and Campylobacter jejuni ATCC 43431 (accession no. Z29326) 
TABLE 1. Pedomicrobium strains used in this study

\begin{tabular}{|c|c|c|}
\hline Microorganism & Strain $^{a}$ & Source $^{a}$ \\
\hline P. americanum & ACM $3090^{\mathrm{T}}$ & IFAM G-1381 $\left(=\operatorname{ATCC} 43612^{\mathrm{T}}\right)$ \\
\hline P. australicum & IFAM ST-1306 ${ }^{\mathrm{T}}$ & IFAM ST- $1306^{\mathrm{T}}\left(=\operatorname{ATCC} 43611^{\mathrm{T}}\right)$ \\
\hline P. australicum & IFAM WD-1355 & IFAM WD-1355 (= ATCC 43614) \\
\hline P. ferruginium & ACM $3037^{\mathrm{T}}$ & IFAM S-1290 ${ }^{\mathrm{T}}\left(=\operatorname{ATCC} 33119^{\mathrm{T}}\right)$ \\
\hline$P$. manganicum & ACM $3038^{\mathrm{T}}$ & IFAM E- $1129^{\mathrm{T}}\left(=\right.$ ATCC $\left.33121^{\mathrm{T}}\right)$ \\
\hline Pedomicrobium sp. & ACM 3067 & ACM 3067 \\
\hline
\end{tabular}

${ }^{a} \mathrm{ACM}$, Australian Collection of Microorganisms, Department of Microbiology, University of Queensland, Brisbane, Australia; IFAM, Institut für Allgemeine Mikrobiologie, Kiel, Germany.

The outgroup chosen for each analysis was the organism most distantly related to the genus Pedomicrobium on the prokaryotic phylogenetic tree (23) in each data set. Unsequenced regions and regions of alignment uncertainty due to length variations were omitted from the analyses. Levels of similarity were calculated for each pair of sequences by using the ae2 editor program (19) and a Sun workstation.

Three different methods available in the PHYLIP version $3.5 \mathrm{c}$ phylogeny inference package (4) were employed to infer the phylogenetic relationships. Pairwise evolutionary distances were computed with DNADIST by using the correction of Jukes and Cantor (16). Phylogenetic trees were constructed by using the neighbor-joining method of Saitou and Nei (26) in the program NEIGHBOR (4). Parsimony and maximum-likelihood analyses were carried out by using DNAPARS and DNAML (4), respectively. Bootstrap analyses that generated 100 data sets were also performed on the phylogeny derived from the neighbour-joining analysis by using the programs SEQBOOT, DNADIST, NEIGHBOR, and CONSENSE (4) to determine the statistical level of confidence for the branch points.

Nucleotide sequence accession numbers. The sequences determined in this study for $P$. australicum IFAM ST-1306 ${ }^{\mathrm{T}}$ (accession no. X97693), $P$. australicum IFAM WD-1355 (accession no. X97694), $P$. americanum ACM $3090^{\mathrm{T}}$ (accession no. X97692), $P$. ferrugineum ACM $3037^{\mathrm{T}}$ (accession no. X97690), P. manganicum ACM $3038^{\mathrm{T}}$ (accession no. X97691), and Pedomicrobium sp. strain ACM 3067 (accession no. X97695) have been deposited in the EMBL database, Cambridge, United Kingdom.

\section{RESULTS AND DISCUSSION}

As the type culture of $P$. australicum had been lost since its description by Gebers and Beese (7), a complete analysis of the phylogenetic relationships among the species of the genus $P e$ domicrobium depended on the ability to extract DNA from nonviable freeze-dried material. Cells of two strains of $P$. australicum that had been freeze-dried in skim milk during the period from 1984 to 1991 were kindly provided by Peter Hirsch. Preliminary experiments (data not shown) performed with cells of Pedomicrobium sp. strain ACM 3067 showed that the presence of $20 \%$ skim milk in the reaction mixtures did not adversely affect extraction of DNA from the cells or interfere with subsequent PCR amplification of the 16S rDNA in the extracted DNA. Extraction of DNA from Pedomicrobium species has been reported to be difficult (12). However, the microwave method of Bollet et al. (2) was found to release sufficient DNA for PCR amplification.

Full 16S rRNA sequences were obtained for the type cultures of the validly published Pedomicrobium species $(20,27)$, as well as for P. australicum IFAM WD-1355 and Pedomicrobium sp. strain ACM 3067. The sequences of the Pedomicrobium strains were found to contain 27 of the $2916 \mathrm{~S}$ rRNA signature sequences for the $\alpha$-Proteobacteria (36), which confirmed membership of the genus Pedomicrobium in the $\alpha$ subdivision (30).

A phylogenetic tree based on Jukes-Cantor evolutionary distances was constructed by using the neighbor-joining method for 1,201 nucleotide positions of the sequences of six Pedomicrobium strains and eight reference species, including four representatives of the hyphal budding bacteria in the $\alpha$-Proteobacteria for which sequences are available for the type

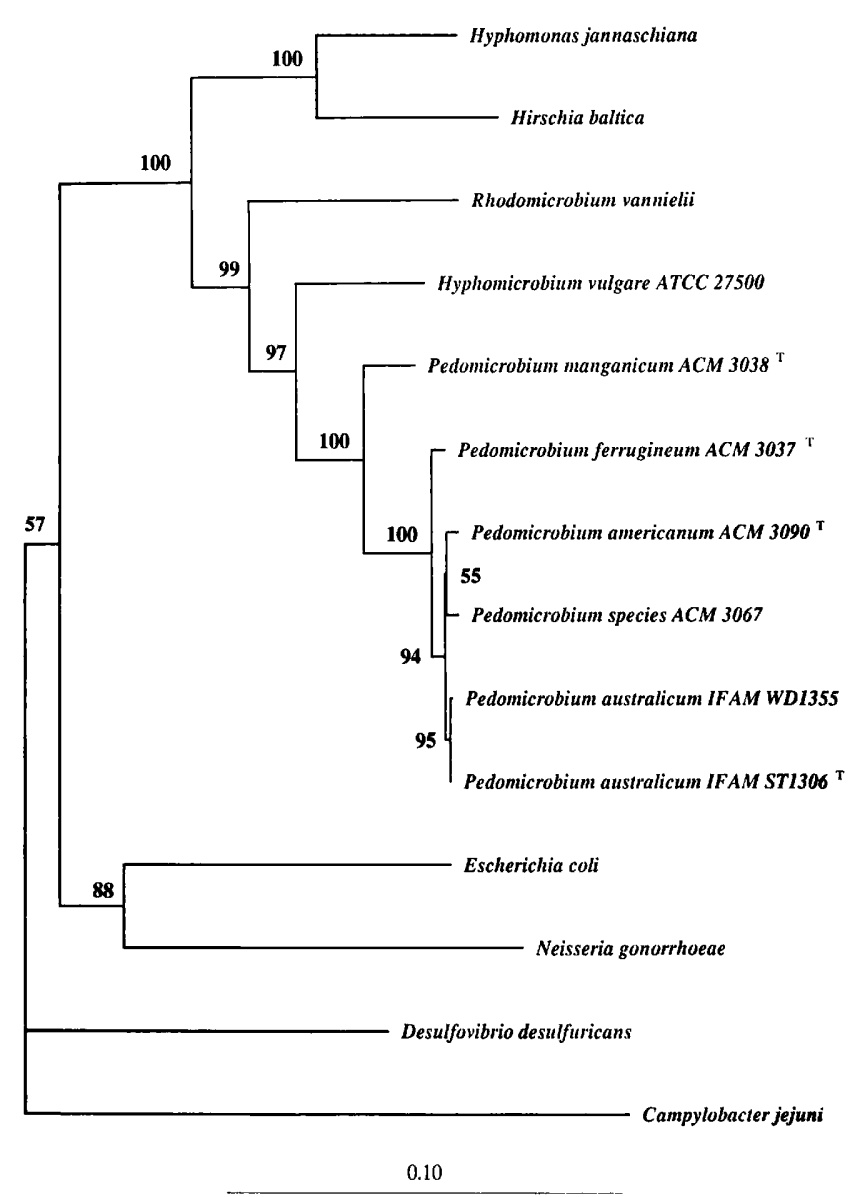

FIG. 1. Neighbor-joining tree showing the relationships among six Pedomicrobium strains, four other hyphal budding bacteria, and representatives of the $\beta-, \delta-, \gamma-$, and $\varepsilon$-Proteobacteria. $C$. jejuni was used as the outgroup. Bootstrap values from 100 analyses are shown at the branch points. Scale bar $=10$ nucleotide substitutions per 100 nucleotides of 16S rRNA sequence.

strains and four representatives of the $\beta-, \gamma-, \delta$, and $\varepsilon$-Proteobacteria (Fig. 1). Phylogenetic trees were also constructed by using the maximum-likelihood and parsimony methods for comparison (data not shown), and the Pedomicrobium species formed a coherent phylogenetic group in all analyses. A bootstrap resampling analysis revealed considerable support ( 97 to $100 \%$ ) for the branch points of the genera of the hyphal budding bacteria. Only one branch point of the species of the genus Pedomicrobium was doubtful (55\% support for the branch point of $P$. americanum and Pedomicrobium sp. strain ACM 3067) (Fig. 1).

A second analysis of the sequences of the Pedomicrobium species over a longer stretch (1,369 nucleotide positions) was performed by using the sequence of the proposed neotype strain ATCC 27500 (= IFAM MC-750) (15) of the nearest relative, Hyphomicrobium vulgare, as the outgroup. The sequences of the two $P$. australicum strains were found to be almost identical (level of similarity, 99.9\%). The species of the genus Pedomicrobium are closely related, with sequence similarities ranging from 96.2 to $99.9 \%$. P . manganicum is phylogenetically the most distantly related species in the genus and exhibits the lowest level of similarity $(96.2 \%)$ with $P$. americanum. Pedomicrobium sp. strain ACM 3067, P. americanum, and $P$. australicum are all very highly related, with sequence similarities of more than $99 \%$. The Australian isolate Pedomicro- 
bium sp. strain ACM 3067 is most similar to P. australicum (level of similarity, 99.6\%) and $P$. americanum (99.4\%). The latter manganese-oxidizing species are more closely related to the iron-oxidizing species $P$. ferrugineum (levels of similarity, 98.8 to $99 \%$ ) than to the other manganese-oxidizing species, $P$. manganicum (levels of similarity, 96.2 to $96.5 \%$ ).

Stackebrandt et al. (30) found in a catalog analysis of $16 \mathrm{~S}$ rRNA oligonucleotides that the genus Pedomicrobium fell within the Hyphomicrobium cluster and questioned the validity of the genus Pedomicrobium. However, there was considerable diversity in the Hyphomicrobium strains studied, which may have been representatives of more than one genus. This view is supported by the rRNA cistron similarity data of Roggentin and Hirsch (24), which showed the phylogenetic heterogeneity of strains currently assigned to the genus Hyphomicrobium. Likewise, the genomic DNA base compositions (9) of the $\mathrm{Hy}$ phomicrobium strains that have been studied are very different, and two of the strains, T-854 and SW-808, are considered only Hyphomicrobium-like (12). This demonstrates the difficulties faced in accurately positioning these organisms, which are closely related phylogenetically and have few differential phenotypic characteristics to accurately define the genus. It is encouraging for the validity of the genus Pedomicrobium that all of its species grouped together to the exclusion of the other genera of hyphal budding bacteria on the basis of their $16 \mathrm{~S}$ rRNA sequences determined in the present study. However, there is only one sequence of a Hyphomicrobium species available for comparison, so these results are not conclusive. A complete data set of the sequences of members of the genus Hyphomicrobium and other genera of the hyphal budding bacteria will be needed to clarify the validity of the genus Pedomicrobium, which has been questioned on the basis of morphology $(1,33)$ and phylogeny $(30)$ and has been supported on the basis of DNA composition $(8,12)$, genome size $(17)$, and DNA homology $(10,11)$.

Because of the high levels of $16 \mathrm{~S}$ rRNA sequence similarity among the species of the genus Pedomicrobium, it is not possible to use this criterion to accurately assign the local isolate Pedomicrobium sp. strain ACM 3067 to one of the existing Pedomicrobium species. However, the 16S rRNA similarity between this isolate and $P$. manganicum is less than $97 \%$, and it is therefore unlikely that strain ACM 3067 belongs to $P$. manganicum, as originally thought $(28,31)$. Because strain ACM 3067 exhibits 98.8 to $99.6 \%$ sequence similarity with $P$. australicum, $P$. americanum, and $P$. ferrugineum, determination of its species status will depend on supporting DNA-DNA homology data or similar evidence obtained by using techniques such as cellular protein polyacrylamide gel electrophoresis patterns. This will not be possible for P. australicum, whose type strain is unavailable.

The taxonomic position of $P$. australicum is problematic and uncertain. Gebers and Beese (7) showed that $P$. australicum was a distinct species on the basis of its DNA-DNA homology values of less than $28 \%$ with all other Pedomicrobium species. However, circumscription of a species also requires phenotypic characteristics to adequately differentiate the organism from other species $(21,35)$, and there are insufficient phenotypic characteristics to differentiate $P$. australicum from $P$. americanum (7). A similar situation exists in the genus Bacillus, in which Fox et al. (5) reported that strains which exhibited more than $99.5 \% 16 \mathrm{~S}$ rRNA sequence similarity and had phenotypic similarities were convincingly established as separate species on the basis of previous DNA-DNA hybridization studies $(5$, $22,25)$. Thus, Fox et al. (5) concluded that some species may not be recognizable from their 16S rRNA gene sequences, even though sequences can be used to distinguish relationships between genera and some well-resolved species.

The taxonomic uncertainty of $P$. australicum is exacerbated by the additional loss of the only other strain studied by Gebers and Beese (7), strain IFAM WD-1355, so the prospect of designating a neotype strain for the species is remote in the absence of suitable differentiating phenotypic characteristics and their close phylogenetic relationships. The objective of finding a neotype strain for $P$. australicum will have to remain unresolved because it is not possible at this time to extract a sufficient quantity of DNA from the freeze-dried ampoules to carry out DNA-DNA hybridization studies.

In view of the absence of a type strain, insufficient phenotypic characteristics to differentiate isolates of closely related species, and the absence of phylogenetic $16 \mathrm{~S}$ rRNA signature sequences, the species $P$. australicum should not be retained. The present research has demonstrated the value of using nonviable preserved specimens to investigate taxonomic issues by molecular methods, as foreshadowed by Sneath (29).

\section{ACKNOWLEDGMENT}

We are indebted to Peter Hirsch, who kindly provided freeze-dried material of the nonviable strains of $P$. australicum.

\section{REFERENCES}

1. Bauld, J., and P. A. Tyler. 1971. Taxonomic implications of reproductive mechanisms of Hyphomicrobium-facies and Pedomicrobium-facies of a ple omorphic budding bacterium. Antonie Leeuwenhoek 37:417-424.

2. Bollet, C., M. J. Gevaudan, X. de Lamballerie, C. Zandotti, and P. de Micco. 1991. A simple method for the isolation of chromosomal DNA from Gram positive or acid-fast bacteria. Nucleic Acids Res. 19:1955.

3. Bond, P. L., P. Hugenholtz, J. Keller, and L. L. Blackall. 1995. Bacterial community structures of phosphate-removing and non-phosphate-removing activated sludges from sequencing batch reactors. Appl. Environ. Microbiol. 61:1910-1916.

4. Felsenstein, J. 1993. PHYLIP—phylogeny inference package (version 3.5c) University of Washington, Seattle.

5. Fox, G. E., J. D. Wisotzkey, and P. Jurtshuk, Jr. 1992. How close is close: 16S rRNA sequence identity may not be sufficient to guarantee species identity. Int. J. Syst. Bacteriol. 42:166-170.

6. Gebers, R. 1981. Enrichment, isolation, and emended description of Pedomicrobium fernigineum Aristovskaya and Pedomicrobium manganicum Aristovskaya. Int. J. Syst. Bacteriol. 31:302-316.

7. Gebers, R., and M. Beese. 1988. Pedomicrobium americanum sp. nov. and Pedomicrobium australicum sp. nov. from aquatic habitats, Pedomicrobium gen. emend., and Pedomicrobium ferrugineum sp. emend. Int. J. Syst. Bacteriol. 38:303-315.

8. Gebers, R., M. Mandel, and P. Hirsch. 1981. Deoxyribonucleic acid base composition and nucleotide distribution of Pedomicrobium spp. Zentralbl Bakteriol. Hyg. Abt. 1 Orig. G 2:332-338.

9. Gebers, R., B. Martens, U. Wehmeyer, and P. Hirsch. 1986. Deoxyribonucleic acid homologies of Hyphomicrobium spp., Hyphomonas spp., and other hyphal budding bacteria. Int. J. Syst. Bacteriol. 36:241-245.

10. Gebers, R., R. L. Moore, and P. Hirsch. 1981. DNA-DNA reassociation studies on the genus Pedomicrobium. FEMS Microbiol. Lett. 11:283-286.

11. Gebers, R., R. L. Moore, and P. Hirsch. 1984. Physiological properties and DNA-DNA homologies of Hyphomonas polymorpha and Hyphomonas neptunium. Syst. Appl. Microbiol. 5:510-517.

12. Gebers, R., U. Wehmeyer, T. Roggentin, H. Schlesner, J. Kölbel-Boelke, and P. Hirsch. 1985. Deoxyribonucleic acid base compositions and nucleotide distributions of 65 strains of budding bacteria. Int. J. Syst. Bacteriol. 35:260269

13. Gherna, R. L. Personal communication.

14. Hirsch, P. Personal communication.

15. Hirsch, P. 1989. Genus Hyphomicrobium, p. 1895-1904. In J. T. Staley, M. P. Bryant, N. Pfennig, and J. G. Holt (ed.), Bergey's manual of systematic bacteriology, vol. 3. Williams \& Wilkins, Baltimore, Md.

16. Jukes, T. H., and C. R. Cantor. 1969. Evolution of protein molecules, p 21-132. In H. N. Munro (ed.), Mammalian protein metabolism. Academic Press, New York, N.Y

17. Kölbel-Boelke, J., R. Gebers, and P. Hirsch. 1985. Genome size determinations for 33 strains of budding bacteria. Int. J. Syst. Bacteriol. 35:270-273.

18. Lane, D. J. 1991. 16S/23S rRNA sequencing, p. 115-163. In E. Stackebrandt and M. Goodfellow (ed.), Nucleic acid techniques in bacterial systematics. John Wiley \& Sons, Chichester, England.

19. Maidak, B. L., N. Larsen, M. J. McCaughey, R. Overbeek, G. J. Olsen, K. 
Fogel, J. Blandy, and C. R. Woese. 1994. The Ribosomal Database Project. Nucleic Acids Res. 22:3485-3487.

20. Moore, W. E. C., and L. V. H. Moore. 1992. Index of the bacterial and yeast nomenclatural changes. American Society for Microbiology, Washington, D.C.

21. Murray, R. G. E., D. J. Brenner, R. R. Colwell, P. De Vos, M. Goodfellow, P. A. D. Grimont, N. Pfennig, E. Stackebrandt, and G. A. Zavarzin. 1990. Report of the Ad Hoc Committee on Approaches to Taxonomy within the Proteobacteria. Int. J. Syst. Bacteriol. 40:213-215.

22. Nakamura, L. K. 1984. Bacillus psychrophilus sp. nov., nom. rev. Int. J. Syst. Bacteriol. 34:121-123.

23. Olsen, G. J., C. R. Woese, and R. Overbeek. 1994. The winds of (evolutionary) change: breathing new life into microbiology. J. Bacteriol. 176:1-6.

24. Roggentin, T., and P. Hirsch. 1989. Ribosomal RNA cistron similarities among Hyphomicrobium species and several other hyphal, budding bacteria. Syst. Appl. Microbiol. 11:140-147.

25. Ruger, H. J., and G. Richter. 1979. Bacillus psychrophilus Larkin and Stokes 1967, a later synonym of Bacillus globisporus Larkin and Stokes 1967. Int. J. Syst. Bacteriol. 29:194-195.

26. Saitou, N., and M. Nei. 1987. The neighbor-joining method: a new method for reconstructing phylogenetic trees. Mol. Biol. Evol, 4:406-425.

27. Skerman, V. B. D., V. McGowan, and P. H. A. Sneath (ed.). 1980. Approved lists of bacterial names. Int. J. Syst. Bacteriol. 30:225-420.

28. Sly, L. I., V. Arunpairojana, and M. C. Hodgkinson. 1988. Pedomicrobium manganicum from drinking-water distribution systems with manganese-re- lated "dirty water" problems. Syst. Appl. Microbiol. 11:75-84

29. Sneath, P. H. A. 1995. Taxonomic note: the potential of dead bacterial specimens for systematic studies. Int. J. Syst. Bacteriol. 45:188-189.

30. Stackebrandt, E., A. Fischer, T. Roggentin, U. Wehmeyer, D. Bomar, and J. Smida. 1988. A phylogenetic survey of budding, and/or prosthecate, nonphototrophic eubacteria: membership of Hyphomicrobium, Hyphomonas, Pedomicrobium, Filomicrobium, Caulobacter and "Dichotomicrobium" to the alpha-subdivision of purple non-sulfur bacteria. Arch. Microbiol. 149:547556.

31. Stackebrandt, E., and B. M. Goebel. 1994. Taxonomic note: a place for DNA-DNA reassociation and $16 \mathrm{~S}$ rRNA sequence analysis in the present species definition in bacteriology. Int. J. Syst. Bacteriol, 44:846-849.

32. Tindall, B. J. Personal communication.

33. Tyler, P., and K. C. Marshall. 1967. Pleomorphy in stalked, budding bacteria. J. Bacteriol. 93:1132-1136.

34. Tyler, P. A., and K. C. Marshall. 1967. Hyphomicrobia-a significant factor in manganese problems. J. Am. Waste Water Assoc. 59:1043-1048.

35. Wayne, L. G., D. J. Brenner, R. R. Colwell, P. A. D. Grimont, O. Kandler, M. I. Krichevsky, L. H. Moore, W. E. C. Moore, R. G. E. Murray, E. Stackebrandt, M. P. Starr, and H. G. Trüper. 1987. Report of the Ad Hoc Committee on Reconciliation of Approaches to Bacterial Systematics. Int. J. Syst. Bacteriol. 37:463-464.

36. Woese, C. R., E. Stackebrandt, T. J. Macke, and G. E. Fox. 1985. A phylogenetic definition of the major eubacterial taxa. Syst. Appl. Microbiol. 6:143151. 